\title{
Evaluation of Receptor Activator of Nuclear Factor Kappa-B Ligand and Osteoprotegerin Levels in Patients with Type 2 Diabetes Mellitus Treated with Oral Anti-diabetics (Sulfonylurea and Metformin) or Insulin: Bone Tissue Perspective
}

\author{
Oral Anti-diyabetik (Sülfonilüre, Metformin) ya da İnsülin ile Tedavi Edilen Tip \\ 2 Diabetes Mellituslu Hastalarda Reseptör Aktivatör Nükleer Kappa-B Ligandı, \\ Osteoprotegerin Düzeylerinin Kemik Dokusu Yönünden İncelenmesi
}

\author{
(D) Alper Gümüși , (D) Muhammed Emin Düz¹, (D) Cihan Coşkun¹, (D) Mustafa Velet², (D) Macit Koldaş1 \\ 1 istanbul Haseki Training and Research Hospital, Clinic of Medical Biochemistry Laboratory, İstanbul, Turkey \\ 2istanbul Haseki Training and Research Hospital, Clinic of Internal Medicine, İstanbul, Turkey
}

\begin{abstract}
Introduction: We aimed to investigate the levels of receptor activator of nuclear factor kappa-b ligand (RANKL) and osteoprotegerin (OPG) in order to evaluate the negative effects of type 2 diabetes mellitus on bone health and their relationship to the severity of disease based on the treatment. We also evaluated the relationship between hemoglobin A1c (HbA1c), parathyroid hormone (PTH) and bone specific alkaline phosphatase (BAP) levels and RANKL and OPG levels.

Methods: The study group consisted of 19 volunteers (15 females and 4 males) and 65 patients with type 2 diabetes mellitus (49 females and 16 males). In order to evaluate the relationship between the treatment and the disease severity, the patient group was divided into two subgroups: patients treated with oral anti-diabetics (OAD) (sulfonylurea and metformin) or insulin. The levels of glucose, calcium, phosphorus, $\mathrm{HbA1c}$, BAP, PTH, RANKL and OPG were compared.

Results: The RANKL and OPG levels of patients treated with insulin were significantly higher than the control group ( $p=0.008, p=0.033$, respectively). However, there was no significant difference in the OAD group for both parameters $(p=0.1, p=0.46$, respectively). There was no significant difference between the groups in terms of PTH and BAP levels ( $p=0.97, p=0.66$, respectively).

Conclusion: We believe that RANKL and OPG levels are higher in patients with poor glycemic control and that they may be indicators of disease severity.

Keywords: Insulin, metformin, osteoprotegerin, receptor activator of nuclear factor kappa-B ligand, sulfonylurea, type 2 diabetes mellitus
\end{abstract}

\section{öZ}

Amaç: Tip 2 diabetes mellitusun kemik sağ|ı̆̆ı üzerindeki olumsuz etkilerini, tedaviye bağlı olarak hastalığın ağırlığı ile olan ilișkisini değerlendirmek için reseptör aktivatör nükleer kappa-B ligandı (RANKL) ile birlikte osteoprotegerin (OPG) düzeylerini araștırdık. Ayrıca hemoglobin A1c (HbA1c), paratiroid hormon (PTH), kemik spesifik alkalen fosfataz (BAP) düzeylerinin hem RANKL hem de OPG düzeyleri ile ilişkisini değerlendirmektir.

Yöntemler: Çalışma grubunu 19 gönüllüden (15 kadın, 4 erkek), hasta grubunu ise 65 tip 2 diabetes mellituslu (49 kadın, 16 erkek) hasta oluşturdu. Uygulanan tedavi ile hastalık ağırlığı arasındaki ilișkiyi değerlendirebilmek için hasta grubu oral anti diyabetik alan (sülfonilüre, metformin) ya da insülin kullananlar olmak üzere iki alt gruba ayrılarak glikoz, kalsiyum, fosfor, HbA1c, BAP, PTH, RANKL, OPG düzeyleri karșılaștıııldı.

Bulgular: Kan glikozun insülinle düzenlenen tip 2 diabetes mellituslu hastaların hem RANKL hem de OPG düzeyleri kontrol grubuna göre anlamlı derecede yüksekti (sırasıyla; $p=0,008, p=0,033)$. Ancak OAD grubu her iki parametre için de farklı değildi (sırasıyla; $p=0,1, p=0,46$ ). Gruplar arasında PTH ve BAP değerleri açısından anlamlı fark yoktu (sırasıyla; $p=0,97, p=0,66)$.

Sonuç: RANKL ile OPG düzeylerinin, glisemik kontrol bozukluğu olan hastalarda daha yüksek olduğunu, hastalık şiddetinin birer göstergesi olabileceğini düșünüyoruz.

Anahtar Kelimeler: İnsülin, metformin, osteorrotegerin, reseptör kapa-B faktörü reseptör etkinleștirici bağlayıcı, sülfonilüre, tip 2 diabetes mellitus 


\section{Introduction}

The World Health Organization reported that the number of patients with diabetes mellitus (DM) reached 422 million in 2014 (1). The prevalence of DM is reported to be between $4.75 \%$ and $11.3 \%$ in Turkey (2). The vast majority of DM patients (90-95\%) suffer from type 2 DM (DM2) (3). DM2 is a disease characterized by hyperinsulinemia and hyperglycemia due to insulin resistance. Hyperglycemia has an important role in the pathogenesis of diabetic complications, because it increases protein glycation and allows gradual accumulation of advanced glycation end products (AGEs) in body tissues. Recent studies suggest that the interaction of AGEs with receptor for AGEs alter intracellular signaling, gene expression, and release pro-inflammatory molecules and free radicals that contribute to the pathology of DM complications (4). These factors lead to a condition characterized by low-level chronic inflammation. By observing immune responses, changes can be observed in many parameters that affect the skeletal system, such as osteocalcin, vitamin-D, adiponectin, leptin, receptor activator of nuclear factor kappa-B ligand (RANKL) and osteoprotegerin (OPG) (5). More commonly recognized DM complications, such as macro vascular disease, retinopathy, nephropathy and neuropathy, DM-related bone disease, have gained growing attention (6). DM2-related bone disease is a latent, progressive pathological process and is difficult to diagnose using routine clinical, radiological and biochemical methods. Although DM2 patients have normal or increased bone density, their bone turnover is reduced and bone quality is altered. Consequently, DM2 patients experience increased bone fragility and fracture risk $(7,8)$. The relationship between DM and bone disease has been known for more than 50 years, and both diseases share similar socio-economic characteristics (9). To clarify this relationship, many different parameters have been evaluated. RANKL and OPG are parameters that are currently being studied to reveal the mechanisms of this relationship.

Bone tissue is constantly renewed due to mechanical stress and hormonal changes. This regeneration depends on the balance between osteoclastic bone resorption and osteoblastic bone formation. RANKL is expressed by osteoblasts and other bone marrow stromal cells, whereas RANK is expressed by other members of pre-osteoclast and osteoclast cells (10). RANKL-RANK interactions activate transcription factors that regulate osteoclastogenesis, resulting in osteoclast assembly and differentiation. OPG, synthesized by osteoblasts, inhibits this interaction by acting as a trap receptor for RANKL and prevents proliferation, differentiation and bone resorption activity of osteoclasts $(11,12)$. OPG is a glycoprotein synthesized by the TNFRSF11B gene located on chromosome 8 and is a cytokine receptor from the tumor necrosis factor receptor superfamily (13). Recent studies suggest that RANKL and OPG have a central role in DM-related bone pathologies (14-17).

Parathyroid hormone (PTH) is a calciotropic hormone that promotes bone resorption and inhibits calcium extraction to maintain adequate levels of plasma calcium. PTH exerts its effects on bone density thorough osteoclasts. Interestingly, PTH receptors are located on osteoblasts. Communication between osteoblasts and osteoclasts is thought to be mediated by RANKL (18). Therefore, if the relationships between RANKL, RANK, OPG and DM-related bone diseases are to be examined, then PTH is an important parameter to be considered. Bone specific alkaline phosphatase (BAP) (EC 3.1.3.1) is considered to be a highly specific marker of bone-forming activity of osteoblasts (19). Previous studies have suggested that serum BAP is useful in predicting bone mineral density $(20,21)$. Therefore, PTH and BAP are useful tools to evaluate the bone turnover process.

Several factors such as hemoglobin A1c ( $\mathrm{HbA} 1 \mathrm{c})$, duration of disease, presence of certain complications and treatment method used, have been used to determine the severity of DM. Some of these variables can be used together to calculate the disease severity index (22). We determined the severity of the disease based on whether patients use insulin treatment because it is a simpler and easier method to determine poor glycemic control. We divided the patient group into two subgroups, as patients receiving oral anti-diabetic (OAD) treatment and patients receiving insulin treatment. If glycemic control could not be achieved with OAD treatments, it was replaced with insulin treatments. Therefore, insulin therapy is an indicator of poor glycemic control and can be used as a marker for assessing the severity of the disease.

In this study, we aimed to investigate the levels of RANKL and OPG in patients and healthy subjects to evaluate the negative effects of DM on bone health, as well as their relationship with the severity of disease, which is determined by the treatment method. In addition, we assessed the relationship between $\mathrm{HbA1C}, \mathrm{PTH}$, and BAP levels and RANKL and OPG levels.

\section{Methods}

\section{Patient Characteristics}

This study was conducted at the Medical Biochemistry Laboratory and Internal Medicine Clinic of İstanbul Haseki Training and Research Hospital in İstanbul. Sixty-five (49 female, 16 male) DM2 patients volunteered for this study and the control group (15 female, 4 male) was selected from healthy volunteers. Consent was obtained from all participants. All the patients were surveyed regarding age, gender, time of diagnosis, smoking history and the presence of other systemic diseases. Patients who suffered from cardiac problems, advanced nephropathy, neurologic symptoms, smoking history and other osteoporotic problems, were excluded from the study. The patients were grouped based on the clinical evaluations by internal medicine specialists. The patient group was divided into two subgroups: patients receiving OAD treatment (OAD group) $(n=25)$ and patients receiving insulin treatment (insulin group) $(n=40)$

Patients in the OAD group were treated with metformin (biguanide group $\mathrm{OAD}$ ) or gliclazide (sulfonylurea group $\mathrm{OAD}$ ) or a combination of two drugs. The insulin group used only insulin preparations and did not receive any additional OAD as part of the treatment protocol. The treatment protocols were unchanged for the participants in the patient groups in the last six months. After the patients fasted for 12-16 hours, venous blood samples were collected in gel-separated tubes without anticoagulants to determine levels of RANKL, OPG and other routine parameters. Serum samples were stored at $-20^{\circ} \mathrm{C}$ for approximately 10 90 days after incubating for 30 minutes, and centrifugation at $1500 \times$ g for 10 minutes. Additionally, whole blood samples were collected in EDTA tubes for HbA1c analysis. 


\section{Analytical Methods}

A solid-phase sandwich immunoassay ELISA kit with a reported linearity range of $31-4000 \mathrm{pg} / \mathrm{mL}$, within-run CV of $2.7 \%$ and within-day CV of $4.5 \%$ (Assaybiotech Omnikine S-RANKL ok-0161, Assaybiotech, California, USA) was used to analyze RANKL levels. Also, another solid-phase sandwich immunoassay ELISA kit with a reported linearity range of 93.7-6000 pg/ $\mathrm{mL}$, within-run CV of $2.2 \%$ and within-day CV of $4.3 \%$ (Immunoleader Boster Technology OPG ek0480, Boster, California, USA) was used to analyze OPG levels.

RANKL and OPG units: RANKL and OPG are not routinely measured, and therefore, there is currently no consensus on units of measurement. Currently, studies report their levels in $\mathrm{ng} / \mathrm{mL}$ for convenience. Therefore, we reported our results using $\mathrm{ng} / \mathrm{mL}$.

HbA1c levels were measured using an HPLC technique via Arkray Adams A1c analyzer (Arkray, Kyoto, Japan). Glucose, calcium, and phosphorus levels were measured via AU2700 (Beckman Coulter, California, USA) biochemistry auto-analyzer. PTH and BAP levels were measured via DXI800 auto-analyzer (Beckman Coulter, California, USA).

\section{Statistical Analysis}

The results were analyzed using the SPSS version 17 (Statistical Package for Social Sciences) software package (IBM, New York, USA). Mean, standard deviation (SD), minimum and maximum values were calculated. Quantitative data were conformed to normal distribution characteristics and groups were treated independently. ANOVA was applied to determine the differences in the measured parameters between the groups with $95 \%$ confidence interval. The probability value (p) was set at $<0.05$. The post-hoc Tukey HSD test was applied for pairwise group comparisons. The power was calculated using the PASS 12 package program (NCSS, Utah, USA).

\section{Ethical Approval}

The authors declare that all procedures performed in studies involving human participants were in accordance with the ethical standards of the institutional and/or national research committee and with the 1964 Helsinki declaration and its later amendments or comparable ethical standards. This study was approved by the Ethics Committee of İstanbul Haseki Training and Research Hospital (decision no: 24.09.2014/181).

\section{Results}

\section{Descriptive Analysis}

Age, gender, duration of disease and duration of insulin use for each group are shown in Table 1. In all groups, gender and age had no significant effect on the parameters measured $(p=0.256, p=0.313$, respectively). The duration of diabetes was significantly different between OAD and insulin groups $(\mathrm{p}<0.05)$.

The power of this study was calculated as 0.9017 using the ANOVA test procedure for all pairs with the current design containing three groups (one control group and two patient groups). The type 1 error ( $\alpha$ value or $p$-value) was set to 0.05 . The power of present study was calculated from the results after the study was completed.

Descriptive statistics of the measured parameters are shown in Table 2.

The bar graphs illustrate the distribution of RANKL and OPG levels between the groups (Figures 1, 2).

The power of this study with the current design, which contains three groups (one control group and two patient groups) was calculated to be 0.88 using ANOVA for all pairs. The type 1 error ( $\alpha$ value or $p$ value) was set at 0.05 . The power of the present study was computed from the results after the study was completed.

\section{Group Comparisons}

The three groups (control, OAD and insulin) were compared using ANOVA and differences in RANKL and OPG levels were observed between the groups ( $p=0.004, p=0.031$, respectively). In order to understand the causes of these differences, we performed a post-hoc Tukey test and observed significant differences between the control group and the insulin group both in RANKL and OPG levels ( $p=0.008, p=0.033$, respectively). However, OAD group did not differ significantly for both parameters ( $p=0.1$, and $p=0.46$, respectively). As expected, HbA1c levels were significantly different between all groups $(p<0.001)$. There was no significant difference between the groups in terms of PTH and BAP levels ( $p=0.97, p=0.66$, respectively).

\section{Correlation of the Evaluated Parameters}

A weak but significantly positive correlation was detected between RANKL and OPG levels by Pearson correlation analysis $(r=0.264, p<0.05)$. Moreover, OPG levels had weak but significantly positive relationships

\begin{tabular}{|l|l|l|l|l|l|l|}
\hline Table 1. The mean age, duration of diabetes mellitus and insulin use for each group \\
\hline
\end{tabular}


with HbA1c levels and DM2 duration $(r=0.230, p<0.05$ and $r=0.242$, $\mathrm{p}<0.05)$.

\section{Discussion}

DM2 is a multi-systemic disease that affects bone tissue by impairing the quality of bone structure and thus increasing bone fragility. The bone is traditionally considered a rigid organ that protects visceral organs and supports the body. However, we now know that bone is a complex and highly active, metabolic and endocrine organ. Energy hemostasis affects bone metabolism and osteocalcin has been reported to mediate this interaction (23). Insulin induces the production of under-carboxylated osteocalcin through post-translational modification in osteoblasts. Increased under-carboxylated osteocalcin stimulates pancreatic insulin

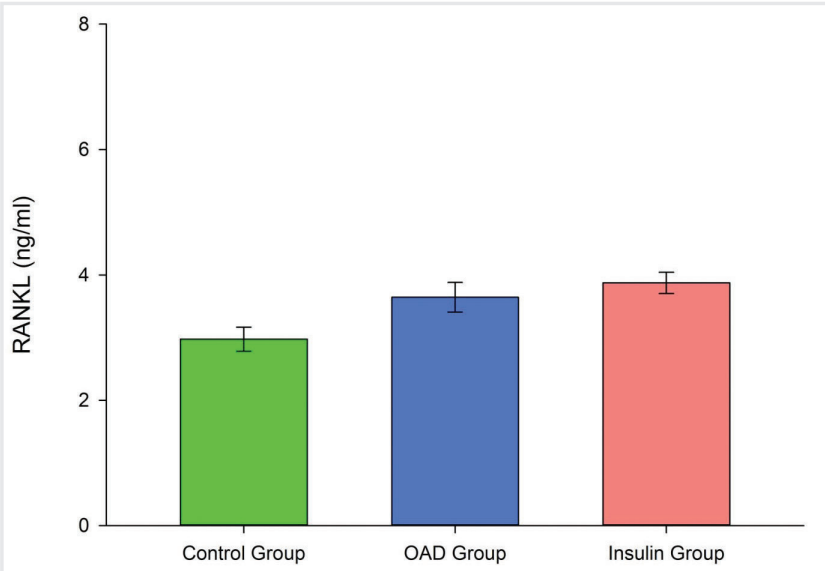

Figure 1. The average Receptor Activator of Nuclear Factor Kappa-B Ligand concentration in each group. The error bars represent the standard errors of the respective groups (control group: 0.19, OAD group: 0.23, insulin group: 0.16).

OAD: oral anti-diabetics, RANKL: receptor activator of nuclear factor kappa-b ligand synthesis and secretion, while increasing adiponectin production in fat tissues, thereby altering energy expenditure by increasing tissue sensitivity to insulin production (24). Adiponectin is a major cytokine secreted from adipocytes during glucose metabolism (25). Adiponectin, which is known to increase insulin sensitivity, has been reported to decrease in patients with DM. Previous studies have shown that adiponectin negatively affects bone formation (26). Increased RANKL and OPG levels have been reported in DM2 (14-17,27). Adiponectin is reported to be the main regulator of OPG levels. There is a negative correlation between adiponectin and OPG levels. In previous studies on OPG and RANKL, experiments have been frequently performed in patients with advanced-stage DM with microvascular pathology or in patients with cardiovascular system problems $(28,29)$.

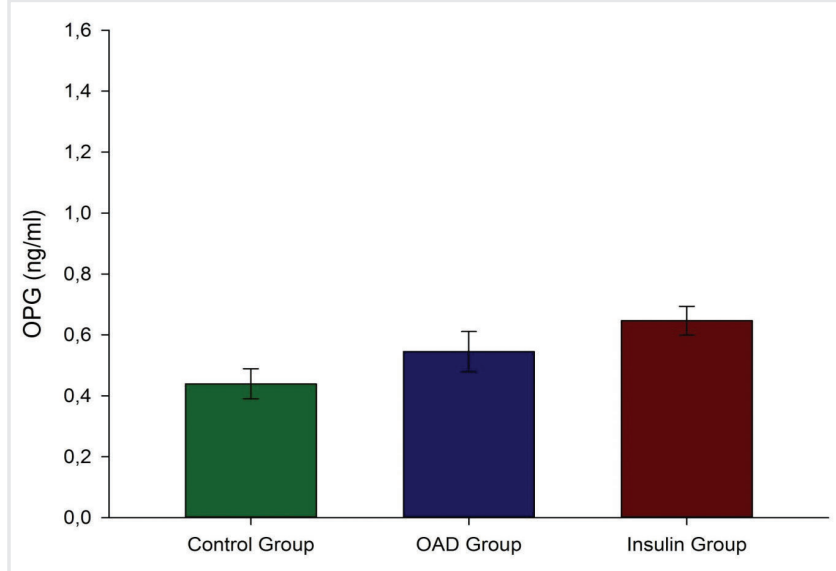

Figure 2. The average Osteoprotegerin concentration in each group. The error bars represent the standard errors of the respective groups (control group: 0.049, OAD group: 0.065, insulin group: 0.040).

OAD: oral anti-diabetics, OPG: osteoprotegerin

Table 2. The mean, standard deviation, minimum and maximum levels of glucose, hemoglobin A1c, calcium, phosphorus, parathyroid hormone, bone specific alkaline phosphatase, receptor activator of nuclear factor kappa-B ligand and osteoprotegerin and the number of subjects $(\mathbf{n})$ in each group. P values obtained from group comparison statistics for each parameter are given in the table

\begin{tabular}{|c|c|c|c|c|c|c|c|c|c|}
\hline & & $\begin{array}{l}\text { Glucose } \\
\text { (mg/dL) }\end{array}$ & $\begin{array}{l}\text { HbA1c } \\
(\%)\end{array}$ & $\begin{array}{l}\mathrm{Ca} \\
(\mathrm{mg} / \mathrm{dL})\end{array}$ & $\begin{array}{l}P \\
(\mathrm{mg} / \mathrm{dL})\end{array}$ & $\begin{array}{l}\text { РTH } \\
(\mathrm{pg} / \mathrm{mL})\end{array}$ & $\begin{array}{l}\text { BAP } \\
(\mu g / L)\end{array}$ & $\begin{array}{l}\text { RANKL } \\
\text { (ng/mL) }\end{array}$ & $\begin{array}{l}\text { OPG } \\
\text { (ng/mL) }\end{array}$ \\
\hline \multirow{4}{*}{$\begin{array}{l}\text { Control } \\
\text { group } \\
(n=19)\end{array}$} & Mean & 95 & 5.3 & 10 & 3.9 & 31.1 & 12.5 & 2.97 & 0.43 \\
\hline & Min & 76 & 4.7 & 9 & 2.5 & 6.3 & 6.3 & 1.67 & 0.09 \\
\hline & Max & 125 & 5.7 & 11.4 & 5.1 & 59.2 & 30.6 & 5 & 0.79 \\
\hline & SD & 11.4 & 0.26 & 0.54 & 0.63 & 13.1 & 5.9 & 0.83 & 0.21 \\
\hline \multirow{4}{*}{$\begin{array}{l}\text { OAD } \\
\text { group } \\
(n=25)\end{array}$} & Mean & 135 & 7.2 & 10.1 & 4.4 & 29.7 & 13.5 & 3.64 & 0.54 \\
\hline & Min & 82 & 5.9 & 9.4 & 3.5 & 15 & 5.6 & 2.06 & 0.01 \\
\hline & Max & 251 & 10.2 & 11.3 & 5.7 & 53 & 30.6 & 6.78 & 1.31 \\
\hline & SD & 43.5 & 1.05 & 0.46 & 0.54 & 11.1 & 5.17 & 1.18 & 0.32 \\
\hline \multirow{4}{*}{$\begin{array}{l}\text { Insulin } \\
\text { group } \\
(n=40)\end{array}$} & Mean & 181 & 8.9 & 10.2 & 4.1 & 31.8 & 12.7 & 3.87 & 0.64 \\
\hline & Min & 95 & 6.5 & 9.5 & 3.2 & 10.6 & 6 & 2.06 & 0.18 \\
\hline & Max & 360 & 13 & 11.4 & 5 & 80.7 & 27.8 & 7.42 & 1.4 \\
\hline & SD & 67.5 & 1.64 & 0.46 & 0.43 & 15.6 & 4.44 & 1.06 & 0.29 \\
\hline \multicolumn{2}{|l|}{$p$} & $<0.001$ & $<0.001$ & 0.091 & 0.07 & 0.975 & 0.66 & 0.031 & 0.004 \\
\hline
\end{tabular}

Min: minimum, Max: maximum, SD: standard deviation, HbA1c: hemoglobin A1c, OAD: oral anti-diabetics, Ca: calcium, P: phosphorus, PTH: parathyroid hormone, BAP: bone specific alkaline phosphatase, RANKL: receptor activator of nuclear factor kappa-b ligand, OPG: osteoprotegerin 
The unique aspect of our study was the investigation of RANKL and OPG levels in patients with DM2 using either OAD or insulin and in healthy volunteers (control group). In addition, we aimed to investigate the effects of disease severity on these parameters.

The RANKL and OPG levels in patients with DM2 using insulin were significantly higher than the control group. Previous studies have reported a higher risk of fracture in DM2 patients treated with insulin $(30,31)$. Yaturu et al. (32) reported increased OPG levels in DM2 patients. The same study indicated a significant relationship between OPG levels and insulin resistance indicators, such as fasting glucose. In our study, the RANKL and OPG levels of patients with DM2 who regulated blood glucose with insulin were significantly higher than the control group and the relationship between OPG levels and HbA1c levels as well as DM2 duration was another finding suggesting that OPG levels were affected by disease severity. Gaudio et al. (33) reported that plasma OPG levels in DM2 patients were significantly higher in the patient groups than in the control group, but the RANKL levels were significantly lower. Additionally, we found that both OPG and RANKL levels were significantly higher in DM2 patients in our study. However, Gaudio et al. (33) performed their study in postmenopausal women and did not conduct treatment-related evaluation of the data between the groups. In support of this information, Jung et al. (34) reported that RANKL levels may be related to the gender of patients.

One of the limitations of our study was the dominance of female gender in all three groups. In such a case, the effect of menopause must be taken into consideration. However, the groups did not differ in terms of age.

Insulin is a metabolic hormone with strong effects on glucose and lipid metabolism. Insulin for DM2 treatment, in addition to its glycemic effects, also acts as an anabolic agent in bone and induces anti-inflammatory effects (35). It has been reported that C-reactive protein levels are lowered in DM2 patients who are being treated with insulin, although the glucose levels remain unchanged (36). On the other hand, previous observations indicate that fracture risk is higher in DM2 patients treated with insulin $(31,37)$. The anti-inflammatory properties of insulin are insufficient to limit the chronic, low-grade inflammation, which is the underlying pathology of DM2. However, insulin treatments are derived from synthetic preparations, and although they treat hyperglycemia, they may not adequately prevent the negative effects due to low levels of chronic inflammation caused by DM2. On the other hand, the adverse effects of DM2 on bone health may cumulatively increase over time. The duration of DM2 was longer in insulin group than in OAD group. Therefore, the adverse effects that are not observed in the early stages may become more pronounced in the advanced stages. Significant differences between the control group and the insulin group may be indicative of this phenomenon.

There were no significant differences between the control group and the OAD group in terms of OPG and RANKL levels. OADs are agents that induce endogenous insulin production. Sulfonylureas are the most common prescribed drug for DM2 treatment. There are studies reporting that sulfonylureas reduce fracture risk in DM2 patients $(37,38)$. Except for enhancing pancreatic insulin secretion, sulfonylureas have no known, direct effect on bone tissue. However the effects of metformin are not limited to insulin release alone. Metformin improves glucose metabolism via activation of adenosine monophosphate (AMP)-activated protein kinases (AMPK), which is also expressed in bone tissue (39). AMPK is a potential stimulator of bone marrow progenitor cells. Stimulation of AMPK results in the activation of osteoblasts in cell culture experiments (40). Shao et al. (41) reported that high serum glucose levels could suppress osteoblast proliferation, but the use of metformin ameliorated this suppression. In addition, metformin is also effective in correcting the pathology underlying diabetes. Zhen et al. (42) reported that treatment with metformin significantly decreases reactive oxygen species production. Experimental studies have implicated that metformin limits osteoclast activity through RANKL (43). Zinman et al. (44) concluded that a combination of metformin and sulfonylurea reduces levels of carboxy-terminal collagen crosslinks that serve as a marker for bone resorption in DM2 patients. Therefore, the OADs evaluated in our study may act as bone preservatives (45). It has been reported that the risk of osteoporotic bone fracture is higher in patients with DM2 who received insulin monotherapy than those receiving combined therapy (46). In our study, the absence of significant differences in RANKL and OPG levels between the OAD group and the control group may be related to the protective effects of OADs.

\section{Conclusion}

We did not observe significant differences between the groups in terms of $\mathrm{Ca}, \mathrm{P}, \mathrm{PTH}$ and BAP levels. In their meta-analysis, Starup-Linde et al. (47) reported that PTH and BAP levels did not significantly differ between diabetic and control groups. Our findings were consistent with their data. We have demonstrated that there are no differences between $\mathrm{OAD}$ and insulin groups.

Although impairment of bone quality could not be conclusively demonstrated with routine assay parameters in terms of $\mathrm{Ca}, \mathrm{P}, \mathrm{PTH}$ and BAP levels, and was not related to disease severity in this study, OPG presented correlation with HbA1c and DM duration. So, OPG may confer benefits in determining and monitoring the DM2-dependent bone quality deterioration, and risk stratification of fractures in diabetics. Additional larger (blood pressure and anthropometric measurements, questioning life-style conditions, other routine laboratory parameters) and long-term (monitoring the individuals) studies are needed to accumulate sufficient data on this subject.

Ethics Committee Approval: This study was approved by the Ethics Committee of Istanbul Haseki Training and Research Hospital (decision number: 24.09.2014/181)

Informed Consent: Consent was obtained from all participants.

Peer-review: Externally peer-reviewed.

Author Contributions: Concept - A.G., M.E.D., C.C., M.V., M.K.; Design - A.G., M.E.D., C.C., M.V., M.K.; Supervision - A.G., M.E.D., C.C., M.V., M.K.; Resources - A.G., M.E.D., C.C., M.V., M.K.; Data Collection and/or Processing - A.G., M.E.D., C.C., M.V., M.K.; Analysis and/or Interpretation - A.G., M.E.D., C.C., M.V., M.K.; Literature Search - A.G., M.E.D., C.C., M.V., 
M.K.; Writing Manuscript - A.G., M.E.D., C.C., M.V., M.K.; Critical Review A.G., M.E.D., C.C., M.V., M.K.

Conflict of Interest: The authors have no conflict of interest to declare.

Financial Disclosure: The authors declared that this study has received no financial support.

\section{References}

1. Global report on diabetes. World Health Organization, Geneva, 2016 http:// apps.who.int/iris/bitstream/10665/204871/1/9789241565257_eng.pdf. Received 12.03.2016.

2. Onat A, Karakoyun S, Akbaş T, Karadeniz FÖ, Karadeniz Y, Çakır H, et al. Turkish adult risk factor survey 2014: Overall mortality and coronary disease incidence in Turkey's geographic regions. Turk Kardiyol Dern Ars 2015; 43: 326-32.

3. American Diabetes Association. Diagnosis and classification of diabetes mellitus. Diabetes Care 2009; 32(Suppl 1): 62-7.

4. Ahmed N. Advanced glycation endproducts-role in pathology of diabetic complications. Diabetes Res Clin Pract 2005; 67: 3-21.

5. Ginaldi L, Martinis DM. Osteoimmunology and beyond. Curr Med Chem 2016; 23: 3754-74.

6. Cade WT. Diabetes-related microvascular and macrovascular diseases in the physical therapy setting. Phys Ther 2008; 88: 1322-35.

7. Motyla KJ, Laura R, Mccabe AB, Schwartzc AV. Bone and glucose metabolism: A two-way street. Arch Biochem Biophys 2010; 503: 2-10.

8. Schwetz V, Pieber T, Obermayer-Pietsch B. The endocrine role of the skeleton: Background and clinical evidence. Eur J Endocrinol 2012; 166: 959-67.

9. Hough, SF. Diabetic osteopenia. Diabetes Res Clin Pract 1989; 7: 161-2.

10. Qiu S, Rao DS, Palnitkar S, Parfitt AM. Differences in osteocyte and lacunar density between black and white American women. Bone 2006; 38: 130-5.

11. Lacey DL, Timms E, Tan HL, Kelley MJ, Dunstan CR, Burgess T, et al. Osteoprotegerin ligand is a cytokine that regulates osteoclast differentiation and activation. Cell 1998; 93: 165-76.

12. Bell NH. RANK ligand and the regulation of skeletal remodeling. J Clin Invest 2003; 111: 1120-2

13. Simonet WS, Lacey DL, Dunstan CR, Kelley M, Chang MS, Lüthy R, et al. Osteoprotegerin: A novel secreted protein involved in the regulation of bone density. Cell 1997; 89: 309-19.

14. Tirosh A. High RANKs for diabetes and osteoporosis. science translational medicine. 2013; 177; 177-49.

15. Bucay N, Sarosi I, Dunstan CR, Morony S, Tarpley J, Capparelli C, et al. Osteoprotegerin-deficient mice develop early onset osteoporosis and arterial calcification. Genes and Development 1998; 12: 1260-8.

16. Galluzzi F, Stagi S, Salti R, Toni S, Piscitelli E, Simonini G, et al. Osteoprotegerin serum levels in children with type 1 diabetes: A potential modulating role in bone status. Eur J Endocrinol 2005; 153: 879-85.

17. García-Hernández A, Arzate H, Gil-Chavarría I, Rojo R, Moreno-Fierros L. High glucose concentrations alter the biomineralization process in human osteoblastic cells. Bone 2012; 50: 276-88.

18. Huang JC, Sakata T, Pfleger LL, Bencsik M, Halloran BP, Bikle DD, et al. PTH Differentially regulates expression of RANKL and OPG. J Bone Miner Res 2003; 19: 235-44.

19. Masrour, R J, Mahjoub, S. Quantification and comparison of bone-specific alkaline phosphatase with two methods in normal and paget's specimens. Caspian J Intern Med 2012; 3: 478-83.
20. Ueda M, Inaba M, Okuno S, Maeno Y, Ishimura E, Yamakawa T, et al. Serum BAP as the clinically useful marker for predicting BMD reduction in diabetic hemodialysis patients with low PTH. Life Sci 2005; 77: 1130-9.

21. Lumachi F, Camozzi V, Tombolan V, Luisetto G. Bone mineral density, osteocalcin, and bone-specific alkaline phosphatase in patients with insulindependent diabetes mellitus. Ann N Y Acad Sci 2009; 1173: Suppl 1: E64-7.

22. Young BA, Lin E, Von Korff M, Simon G, Ciechanowski P, Ludman EJ, et al. Diabetes complications severity index and risk of mortality, hospitalization, and healthcare utilization. Am J Manag Care 2008; 14: 15-23.

23. Lee NK, Sowa H, Hinoi E, Ferron M, Ahn JD, Confavreux C, et al. Endocrine regulation of energy metabolism by the skeleton. Cell 2007; 130: 456-69.

24. Ferron M, Hinoi E, Karsenty G, Ducy P. Osteocalcin differentially regulates beta cell and adipocyte gene expression and affects the development of metabolic diseases in wild-type mice. Proc Natl Acad Sci U S A 2008; 105: 5266-70.

25. Yamamoto S, Matsushita $Y$, Nakagawa T, Hayashi T, Noda M, Mizoue T. Circulating adiponectin levels and risk of type 2 diabetes in the Japanese. Nutr Diabetes 2014; 4: e130.

26. Kanazawa I, Yamaguchi T, Yamamoto M, Yamauchi M, Yano S, Sugimoto T. Relationships between serum adiponectin levels versus bone mineral density bone metabolic markers, and vertebral fractures in type 2 diabetes mellitus. Eur J Endocrinol 2008; 160: 265-73.

27. Chen WJ, Rijzewijk LJ, van der Meer RW, Heymans MW, van Duinkerken E, Lubberink M, et al. Association of plasma osteoprotegerin and adiponectin with arterial function cardiac function and metabolism in asymptomatic type 2 diabetic men. Cardiovasc Diabetol 2011; 10: 67.

28. Gordin D, Soro-Paavonen A, Thomas MC, Harjutsalo V, Saraheimo M. Osteoprotegerin Is an Independent predictor of vascular events in finnish adults with type 1 diabetes. Diabetes Care 2013; 36: 1827-33.

29. Bjerre $\mathrm{M}$. Osteoprotegerin $(\mathrm{OPG})$ as a biomarker for diabetic cardiovascular complications. Springer Plus 2013; 2: 658.

30. Janghorbani M, Feskanich D, Willett WC, Hu F. Prospective study of diabetes and risk of hip fracture: The Nurses' Health Study. Diabetes Care 2006; 29: 1573-8.

31. Napoli N, Strotmeyer ES, Ensrud KE, Sellmeyer DE, Bauer DC Andrew R, Hoffman AR, et al. Fracture risk in diabetic elderly men: the MrOS study. Diabetologia 2014; 57: 2057-65.

32. Yaturu S, Rains J, Jain SK. Relationship of elevated osteoprotegerin with insulin resistance, CRP, and TNF-alpha levels in men with type 2 diabetes. Cytokine 2008; 44; 168-71.

33. Gaudio A, Privitera F, Pulvirenti I, Canzonieri E, Rapisarda R, Fiore CE. Relationships between osteoprotegerin, receptor activator of the nuclear factor kB ligand and serum levels and carotid intima-media thickness in patients with type 2 diabetes mellitus. Panminerva Med 2014: 56; 221-5.

34. Jung K, Lein M, Hösslin Kv, Grosse A, Roth S, Possinger K, Lüftner D. Osteoprotegerin and receptor activator of nuclearfactor-kappa Bligand (RANKL) in the serum of healthy adults. Int J Biol Markers 2002; 17: 177-81.

35. Thrailkill KM, Lumpkin CK, Jr Bunn RC, Kemp SF, Fowlkes JL. Is insulin an anabolic agent in bone? Dissecting the diabetic bone for clues. Am J Physiol Endocrinol Metab 2005; 289: E735-45.

36. Kothari VI, Galdo JA, Mathews ST. Hypoglycemic agents and potential antiinflammatory activity. J Inflamm Res 2016; 9: 27-38

37. Monami M, Cresci B, Colombini A, Pala L, Balzi D, Gori F, Chiasserini V, et al. Bone fractures and hypoglycemic treatment in type 2 diabetic patients: a case-control study. Diabetes Care 2008; 31: 199-203.

38. Vestergaard P, Rejnmark L, Mosekilde L. Relative fracture risk in patients with diabetes mellitus, and the impact of insulin and oral antidiabetic medication on relative fracture risk. Diabetologia 2005;48: 1292-9. 
39. Musi N, Hirshman MF, Nygren J, Svanfeldt M, Bavenholm P, Rooyackers O, et al. Metformin increases AMP-activated protein kinase activity in skeletal muscle of subjects with type 2 diabetes. Diabetes 2002; 51 :2074-81.

40. Kanazawa I, Yamaguchi T, Yano S, Yamauchi M, Yamamoto M, Sugimoto T. Adiponectin and AMP kinase activator stimulate proliferation, differentiation, and mineralization of osteoblastic MC3T3-E1 cells. BMC Cell Biol 2007; 8: 51.

41. Shao X, Cao X, Song G, Zhao Y, Shi B. Metformin Rescues the MG63 Osteoblasts against the Effect of High Glucose on Proliferation. J Diabetes Res 2014; 453940.

42. Zhen D, Chen $Y$, Tang X. Metformin reverses the deleterious effects of high glucose on osteoblast function. J Diabetes Complications 2010; 24: 334-44.

43. Mai QG, Zhang ZM, Xu S, Lu M, Zhou RP, Zhao L, et al. Metformin stimulates osteoprotegerin and reduces RANKL expression in osteoblasts and ovariectomized rats. J Cell Biochem 2011; 112: 2902-9.
44. Zinman B, Haffner SM, Herman WH, Holman RR, Lachin JM, Kravitz BG, et al. Effect of rosiglitazone, metformin, and glyburide on bone biomarkers in patients with type 2 diabetes. J Clin Endocrinol Metab 2010; 95: 134-42.

45. Gilbert MP, Pratley RE. The impact of diabetes treatments on bone health in patients with type 2 diabetes mellitus. Endocr Rev 2015; 36: 194-213.

46. Losada E, Soldevila B, Ali MS, Martínez-Laguna D, Nogués X, Puig-Domingo M. Real-world antidiabetic drug use and fracture risk in 12,277 patients with type 2 diabetes mellitus: a nested case-control study. Osteoporos Int 2018; 29 : 2079-86.

47. Starup-Linde J, Eriksen SA, Lykkeboe S, Handberg A, Vestergaard P. Biochemical markers of bone turnover in diabetes patients-a meta-analysis, and a methodological study on the effects of glucose on bone markers. J Osteoporos Int 2014; 25: 1697-708. 